\section{B A Institute of \\ YK Business Administration \\ TK \\ Karachi \\ Leadership and Ideas for Tomorrow}

Business Review

Volume 10 Issue 1 January - June 2015

$1-1-2015$

\title{
What lies at the core of core inflation? An empirical analysis to identify the determinants of core inflation in Pakistan
}

\author{
Mehwish Ghulam Ali \\ Institute of Business Administration, Karachi, Pakistan \\ Muhammad Ather Elahi \\ Institute of Business Administration, Karachi, Pakistan \\ Qazi Masood Ahmed \\ Institute of Business Administration, Karachi, Pakistan
}

Follow this and additional works at: https://ir.iba.edu.pk/businessreview

Part of the Growth and Development Commons, Income Distribution Commons, Macroeconomics Commons, and the Regional Economics Commons

\section{(c) (9)}

This work is licensed under a Creative Commons Attribution 4.0 International License.

\section{Recommended Citation}

Ali, M. G., Elahi, M. A., \& Ahmed, Q. M. (2015). What lies at the core of core inflation? An empirical analysis to identify the determinants of core inflation in Pakistan. Business Review, 10(1), 47-60. Retrieved from https://doi.org/10.54784/1990-6587.1313

This article is brought to you by iRepository for open access under the Creative Commons Attribution 4.0 License and is available at https://ir.iba.edu.pk/businessreview/vol10/iss1/5. For more information, please contact irepository@iba.edu.pk. 
https://ir.iba.edu.pk/businessreview/vol10/iss1/5

DOI: https://doi.org/10.54784/1990-6587.1313

Business Review - Volume 10 Number 1

January - June 2015

\title{
ARTICLE
}

\section{WHAT LIES AT THE CORE OF CORE INFLATION? AN EMPIRICAL ANALYSISTO IDENTIFY THE DETERMINANTS OF CORE INFLATION IN PAKISTAN}

\author{
Mehwish Ghulam Ali \\ Institute of Business Administration, Karachi Pakistan \\ Muhammad Ather Elahi \\ Institute of Business Administration, Karachi Pakistan \\ Qazi Masood Ahmed \\ Institute of Business Administration, Karachi Pakistan
}

\begin{abstract}
Core inflation leads to erosion of purchasing power and distorts income distribution in favour of the rich and the creditors. Further, it aggravates poverty due to its regressive effect. By targeting core inflation, the Central Bank attempts to reduce poverty and improve income distribution. The Central Bank does and should target core inflation for the aforementioned objectives, hence it becomes necessary to identify if factors apart from monetary policy affect core inflation. This paper aims to identify the determinants of core inflation in Pakistan. This study is motivated by the lack of work done in identifying the determinants of core inflation in Pakistan. Using OLS analysis, we find that adaptive expectations, loans to private sector, real GDP growth rate and exchange rate all impact core inflation. Adaptive expectations are the largest contributor to core inflation.
\end{abstract}

Keywords: Inflation, Monetary Policy

\section{JEL Classification:E31,E52}

\section{Introduction}

A low and stable level of inflation is necessary for economic growth, but if it exceeds a threshold level it will cause more harm than good to the economy. In the case of Pakistan the threshold level is 9 percent based on CPI headline inflation (Mubarik, 2005). However, using headline inflation may not always be a preferred option for policy making. This is because headline inflation is affected by transitory changes in prices that are not in the control of monetary authorities. Under the umbrella of "inflation" we find three categories namely food inflation, non-food (also sometimes referred to as fuel inflation) inflation and core inflation. While food and fuel inflation are self-explanatory terms, core inflation warrants some introduction. It is the long run trend of inflation and is most commonly referred to food non fuel inflation. Specifically, it is headline inflation adjusted for transient and non-monetary shocks. All three categories i.e. food, fuel and core inflation, contribute to overall inflation rate in the economy and each of the three is affected by different factors. Knowledge of the causes of the transitory component and general trend is important for policy makers for devising the most suitable policies. 
In recent times, an increasing number of Central Banks are identifying price stability as their operational goal. This is because inflation leads to erosion of purchasing power and distorts income distribution in favour of the rich and creditors. Further, it aggravates poverty due to its regressive effect. By targeting inflation, the Central Banks attempt to reduce poverty and improve income distribution. Identifying the determinants of each type of inflation will help identify which policy makers are most apt to deal with which kind of inflation. Policies to counter food and fuel inflation may not fall directly under the domain of the Central Bank whose focus is core inflation. The tools available to the Central Bank, when addressing inflation, are the various channels of the monetary policy transmission mechanism. There exists a gap when the question comes of identifying how these and other factors affect core inflation. This hidden information about core inflation needs to be extracted. In this paper we conduct this exercise for Pakistan by analyzing the determinants of core inflation. At policy level, the knowledge will help in better management of monetary policy in Pakistan

The objectives of this paper are threefold:

1. A re-assessment of the relationship between monetary policy and core inflation in Pakistan.

2. An analysis of the determinants of core inflation in Pakistan i.e. once adjusting for transient and non-monetary shocks are there any factors, including transmission mechanism of monetary policy, which systematically affect inflation in the long run

3. An empirical estimation of the contribution of determinants of core inflation in Pakistan.

Using data from 1981-2012, this paper attempts to understand what factors affect core inflation. The rest of the paper is organized as follows: Section II provides a review of literature, Section III discusses the trend of core inflation in Pakistan, Section IV discusses data and methodology, Section V provides results and Section VI concludes.

\section{Review of Literature}

Calculation of Core Inflation

The first step is to understand how core inflation is calculated. We explore the methods employed by the State Bank of Pakistan to calculate core inflation. (Tahir, 2003) Explains that CPI changes are both positively skewed and leptokurtic in Pakistan. This means that for the CPI, exceptionally large price changes are more common than in a normal distribution and that exceptional price rises are more common than exceptional price declines. Headline inflation, is not a robust estimator for studying the general trend of inflation. Two methods for estimating core inflation are provided by the author: exclusion approach and trimmed mean approach.

The exclusion approach excludes prices of food and energy groups from the calculation of core inflation. While this method is transparent and easily verifiable, the exclusion is arbitrary. Another limitation in this approach is potential information loss due to exclusion of food and energy prices. And finally, excluding food and energy groups does not guarantee that the remaining price items will not include transitory shocks.

This justifies use of the second method which is the Trimmed Mean Approach. In this approach price changes are arranged from lowest to highest in each period and then zero weights are attached to a fixed percentage of items from both ends of the tails while 
calculating the mean. This removes the need to exclude any item a priori. However, the percentage of items to which zero weights need to be attached still needs to be decided. For a core inflation measure to be accurate it should fulfill two criteria. One is that over a long period of time average rate for both core and headline inflation is the same. The rationale is that in the long run transitory effects die down. The second is that core inflation should move closely with the trend rate of inflation. The author finds that trimmed mean levels of core inflation at $10 \%, 15 \%$ and $20 \%$ all fulfill the first criteria. Further, out of the three trimming at $15 \%$ seems to fulfill the second criteria best. ${ }^{1}$

There is no one infallible measure of calculating core inflation(Lodhi, 2007)evaluates the core inflation measures in Pakistan and discusses the limitations of the exclusion and trimmed mean approach. He finds that exclusion approach is not strictly exogenous and has dual causation with headline inflation. Trimmed mean approach while satisfying the erogeneity criteria systematically understates true core inflation because of uniformly trimming from the top and bottom of the distribution.

For a policy maker, knowing what determines inflation is as important as studying its trend. (Khan \& Schimmelpfennig, 2006)correctly point out that if inflation in Pakistan is a monetary phenomenon then the Central Bank is right authority to tackle it, however if it is affected by supply side factors such as support prices of wheat then it should be tackled by Ministry of Agriculture. They find that in the short run wheat support prices affect inflation while in the long run it remains a monetary phenomenon with a one year lag.

Adaptive expectations play a key role in determining the rate of inflation. ( Khan, Bukhari, \& Ahmed, 2007)address this question when they study the effect of both demand and supply side factors on headline inflation in Pakistan. They find that historically and more recently till 2005-06 adaptive expectations contributes have a pivotal effect on headline inflation. This is through the food channel, which comprises of half the budget for household expenditures.

Much work has been done to see what affects food and non-food inflation. (Khan \& Qasim, 1996) disaggregate inflation into food and non-food inflation. Further they calculate non-food inflation by deriving the residual from total inflation when effect of food inflation has been extracted. Using co integration they find current money supply to impact overall inflation, food inflation and non-food inflation positively. The inertia effect of money supply on overall inflation and non-food is positive but wears off. Imported prices have a positive effect on overall and non-food inflation but the effect wears off subsequently as well. All three inflation categories have a negative relationship with supply side variables suggesting that an increase in GDP (food and non-food) would lead to a reduction in inflation. Wheat support price has a huge and positive impact on food inflation.

\section{Determinants of Core Inflation}

The Central Bank targets core inflation for price stability either through money supply or interest rate. These two factors individually and jointly affect macroeconomic variables through various channels. For Pakistan, the four most pertinent channels are: the

\footnotetext{
'(Riazuddin, Lodhi, Ashfaq, \& Ahmad, 2013)have worked further using the Trimmed Mean Approach to calculate core inflation based exclusively on the permanent part of CPI based on monthly data. This allows including those food and fuel items that display persistent price behaviour in Pakistan. This new measure has been named Relatively Stable Component of CPI (RSC-CPI)
} 
interest rate channel, the credit channel, asset price channel and the exchange rate channel. This mechanism has also been known as the transmission mechanism of monetary policy.(Agha, Ahmed, Mubarik, \& Shah, 2005)A discussion of each of these branches follows.

The process for changing money supply starts with open market operations and from there it can affect the economy jointly or individually through any of the following channels. Altering the discount rate directly affects market interest rates and deposit and lending rates of the banking sector. This is the interest rate channel. A higher discount rate (or a lower money supply) would affect the loans made out by commercial banks through the credit channel. Current monetary policy and expectations about future monetary policy based on the present can lead to revision in asset prices (e.g. changes in the stock market index) through the asset price channel. The exchange rate channel can affect prices directly though price of imports (though it might have more of an effect on headline inflation rather than core inflation). It can also have an effect through speculation. ${ }^{2}$

In determining the long term trend of prices, it is expected that people will use past prices in forming perceptions about future prices i.e. in the absence of complete information, it can be expected that people will assume, in some part, that the trend of prices which has occurred in the past can be expected to continue in the future. If prices have been high in the past, people will predict prices to be higher in the future as well. This predictive behaviour of people then becomes a self-fulfilling prophecy ${ }^{3}$. However, given additional information, people will revise their perceptions. This is where the role of a central bank is pivotal. If a central bank announces and goes on to implement a monetary policy which causes people to revise their perceptions of prices in a desired manner then that policy of the central bank is credible. However, if people do not revise their perceptions, even after a policy has been set in place, then that policy is not effective in controlling core inflation. In reality it may be the case the individuals use both their past perceptions and review their perceptions after policy measures.

\section{Trend Analysis}

Figure 1 shows the trend of core inflation from 1984-2011. From Mid 1980's to 1990 core inflation was at $4.87 \%$. But in the early 1990 's core inflation increased sharply before following a downward trend with the average rate for the period 1990-1995 being in double digits at $12.4 \%$. The 1990 s were an era of trade liberalization policies and changing governments. In 1988 Pakistan moved from a military regime to a democratic government where Benazir Bhutto became the prime minister of Pakistan. In 1991 there is a structural break in core inflation, with core inflation sky rocketing to $18 \%$ and reaching a high of $30 \%$ in 1992 before falling sharply to slightly below $10 \%$ in 1993. In July 1998 the Pakistani exchange rate shifted to a managed exchange rate. In 1999 the democratic government was overthrown in a military coup by General Pervez Musharraf. This accounts for the second structural break in 1999 when core inflation increased from about $10 \%$ to $17 \%$.

Figure 1: Core Inflation In Pakistan 1984-2011 (Appendix Page 56)

\footnotetext{
2http://www.ecb.europa.eu/mopo/intro/transmission/html/index.en.html

${ }^{3}$ E.g. if shop keepers will raise prices, expecting market prices to be higher and in turn market prices will actually become higher since the shop keepers increased their own prices to begin with.
} 
During the military rule of General Pervaiz Musharraf core inflation is seen to fall in the 2000's. Generally military regimes are known to favour the reduction in populist policies which lead to lower and more disciplined government borrowing. Core inflation fell sharply in 2000 and then remained at a low level till 2003 before beginning a rising trend from 2004. It would be imprudent not to mention here that the terrorist attacks of 9/11 and Pakistan's joining the war on terror led to an increase in foreign inflows into the country and could explain the decrease in government borrowing from domestic sources. A rapid monetary expansion in 2004-2005 led to an increase in core inflation in the following years. In 2008 Musharraf resigned and the impact was felt immediately with core inflation increasing amongst this uncertainty in 2009. In 2008/2009 there was a sharp increase in core inflation which was at high of $18.75 \%$ in the second quarter of 2009 and then gradually settled at $10.71 \%$ in the second quarter of 2010 . Since then it has hovered near the $10 \%$ level.

\section{Core Inflation and Monetary Policy}

The inflation rate which State Bank would focus on is the core inflation. It warrants asking whether there has been any systematic relationship between the monetary policy and core inflation.

Figure 2 illustrates the relationship between the growth in broad based money supply and core inflation across time. ${ }^{4}$ The graph suggests that a decrease in money supply (tightening of monetary policy) leads to an increase in core inflation (e.g. growth in money supply was falling in periods from 1988-1990, 1993-1996, 1998-2000 but core inflation has been increasing, relatively stable and increasing respectively. Growth in money supply is highly fluctuating from 2001-2007 however core inflation remained relatively stable before increasing. From then from 2008-2010 money supply increased but so did inflation.

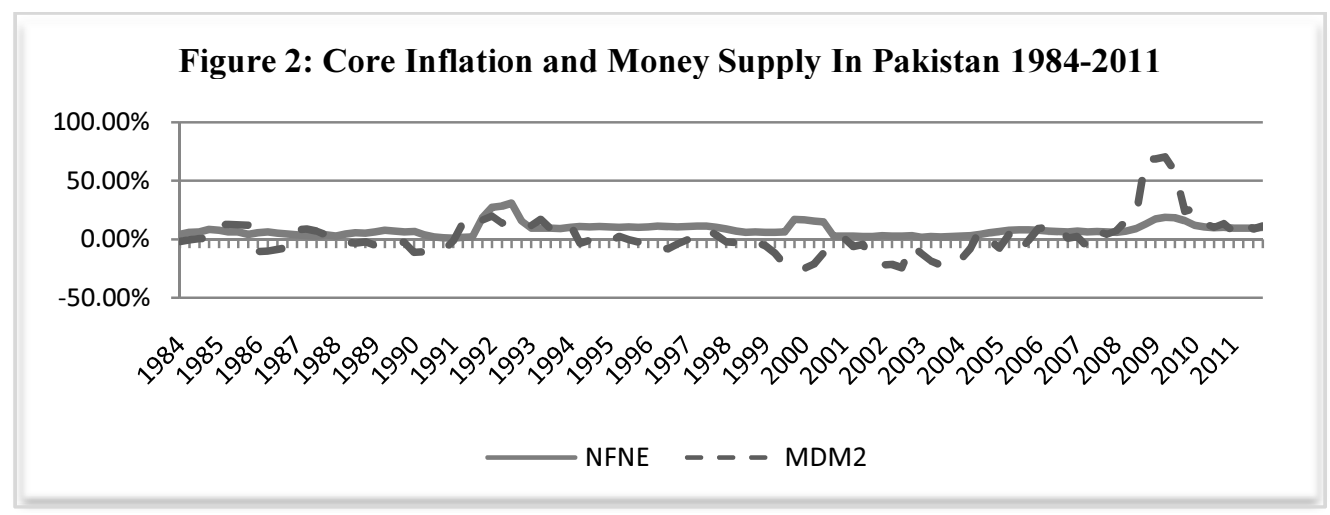

Figure 2 illustrates that a tightening of monetary policy is actually leading to an increase in core inflation. This has been described as the price puzzle by (Javid \& Munir, 2013). They describe this puzzle as an increase in interest rates leads to an increase and not decrease in prices.

\footnotetext{
${ }^{4}$ We have not shown the relationship between core inflation and discount rate since discount rate has been only a recent tool in controlling inflation. The relationship is shown in Appendix A1
} 
The decrease in prices due to a tightening of monetary policy comes much later(Javid \& Munir, 2013) The impact of money supply on the price level is seen 4-6 quarters after the policy has been implemented. If money supply was changed in $\mathrm{t}=0$, the effect on prices would be seen in year $t=1$ or year $t=1.5$. Figure 3 illustrates that money supply growth at a lag of $6^{5}$ quarters follows a closer relationship with core inflation than current money supply growth.

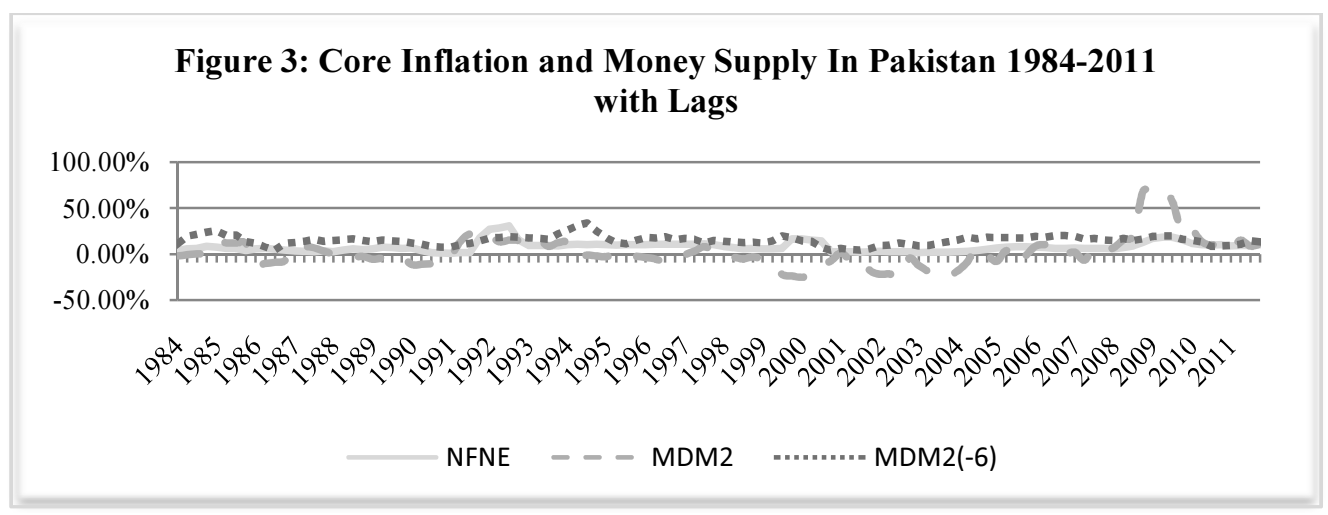

This answers the first objective i.e. is there a relationship between core inflation and monetary policy. We find that a relationship does exist between current money supply and core inflation though not one we would expect. We also find that money supply seems to have the desired effect on core inflation after a lag of 6 quarters.

What are the various channels through which monetary policy affects core inflation? Apart from monetary policy do some other factors systematically affect core inflation? We address these questions in our next section.

\section{Data and methodology}

Table 1 : List of Variables with Descriptive Statistics

The time period of data is from 1981 to 2012 . Table 1 provides descriptive statistics of the data used. The major focus in designing methodology was to provide a comprehensive list of factors affecting core inflation. The following equation was estimated:

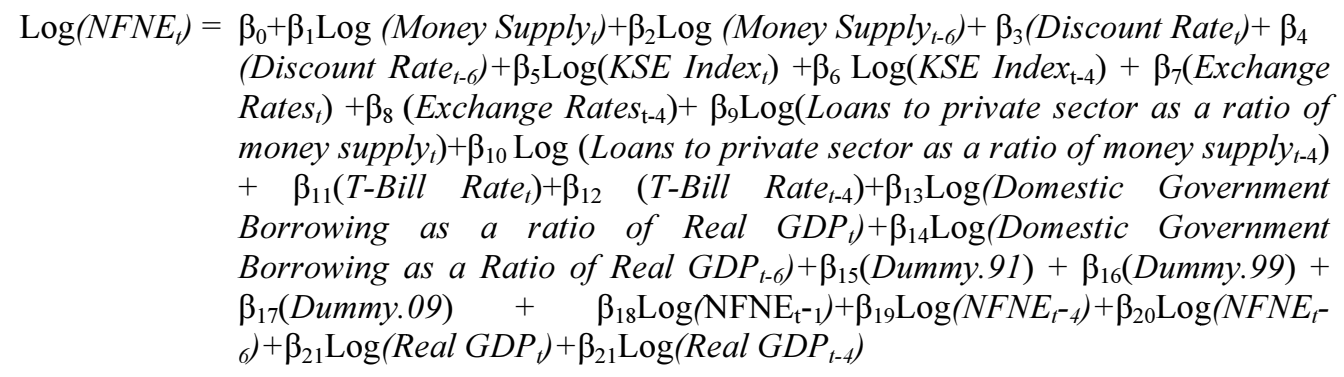

\footnotetext{
${ }^{5}$ We conducted a similar exercise for money supply with a lag of 4 quarters (12 months).
} 
In the above specification, NFNE is Non Food Non Energy Inflation. Money supply, discount rate and four channels of monetary policy transmission mechanism are used to determine core inflation. These include KSE Index, Exchange rates, loans to private sector, real GDP growth rate and t-bill rate. We include domestic government borrowing because of inflationary pressures of government borrowing on headline inflation. Time dummies specify structural breaks in data.

Any factor which will have a persistent effect on inflation in the long run will also affect core inflation. Adaptive expectation plays a critical role in the persistence of trend of inflation. Even when volatility in prices is not considered, people take current prices as a measure by which to gauge and predict what future prices might be. If current prices are high, then even under normal demand and supply conditions of economy these higher prices will be carried forward because people will expect them to be higher. This in turn will affect how people perceive their salaries and expenditures should change in order to keep purchasing power constant, whether they should buy certain goods today in the anticipation of higher prices in the future, there might be speculator pressures in asset and credit markets and resources may be diverted from investments into manufacturing good into savings today in lieu of expectations of higher prices in the future. If on average the expectation of higher prices in the future is a trend, then this will translate in higher prices in the future even in the absence of shocks to the system. To capture this effect the lags of NFNE are taken at 4 and 6 quarters The expected sign is positive i.e. since people on average assume prices to be higher in future, then on average a long term trend of higher prices is observed.

To study the impact of the transmission mechanism of monetary policy on core inflation, we look at the following variables: Broad Money M2, Discount Rate, Loans to private sector as a ratio of money supply, T-bill rate, Karachi stock exchange index and real effective exchange rate. An explanation for the use of these variables has already been described previously.

The effect of domestic government borrowing on core inflation can go either way depending on how the money is spent and more importantly how the debt is serviced. If the money is spent in lucrative economic activities, then theoretically, the government debt should refinance itself. If however, the money was not spent in profitable economic activities then the government debt can be financed by printing money or monetization of debt. This will lead to inflationary pressures. In essence the amount of nominal goods in the economy would increase (currency) while the amount of real goods in the economy would not (It could remain unchanged or fall). Either way this would drive up prices. If on average monetization of debt is a frequent occurrence in an economy then this would affect core inflation. The amount of the effect would vary depending on how far the economy is from the potential.

The impact of real GDP on core inflation can go either way. In case of the economy operating near full employment levels, an increase in real GDP can induce inflation. However, for countries operating away from full employment level i.e. countries where there is unutilized excess capacity then an increase in real GDP can actually reduce inflationary pressures. For Pakistan, we expect this effect to be negative.

The dummy variables have been included to account for structural break in data at time periods 1991, 1999 and 2009. 


\section{Results}

The first task was to check the stationary conditions of the variables under consideration. For this we apply the Augmented Dicky-Fuller Test to check whether any variable has a unit root. The results indicate that all variables except growth in KSE Index and growth in exchange rate have a unit root at level but not at first difference.

\section{Table 2: Augmented Dickey-Fuller Test of Residuals}

All coefficients, except the time dummies, discount rate and t bill rate are in log form along with the dependent variable NFNE and hence they can be interpreted as elasticity

\section{Table 3: Dependent Variable Core Inflation (Non Food Non energy)}

Immediate impact of adaptive expectations is significant but further impacts are not. Of the four channels of monetary policy transmission mechanism, the credit channel and the exchange rate channel have a significant impact on core inflation. The credit channel operates through loans to private sector as a ratio of money supply and real GDP. Both current and lagged loans to private sector as a ratio of money supply are significant. Current real GDP is highly significant whereas lagged real GDP is weakly significant. Current exchange rates do not have an impact on core inflation but lagged exchange rates are significant. The interest channel and the asset price channel are insignificant. Once accounting for these channels, both monetary policy instruments are insignificant and so is government borrowing. Of the three time dummies, 1999 and 2009 are significant.

Adaptive expectations, current loans to private sector, lagged exchange rate and time dummies all have a positive impact on inflation, as expected and discussed. Current and lagged real GDP have a negative impact on core inflation.

Figure 4 summarizes the contribution of each determinant to total core inflation. It is striking that adaptive expectations consistently affect core inflation.

A look at figure 4 reveals that from mid-1980 to mid-2005 the role of adaptive expectations in determining core inflation was increasing. This era was characterised as one with a high level of uncertainty. This era saw a shift in government from military dictatorship to democracy to a military coup. Pakistan had nine different governments from 1988-2001 and entered into 9 different IMF agreements (Husain, 2002). As Pakistan began to experience trade liberalization she also underwent exchange change regime transformations.(Hamid \& Hamid, 1982)Amidst this uncertainty, it can be expected that role of adaptive expectations be large. Exchange rate was contributing significantly and positively to the core inflation. This is most evident in the mid-1980s and mid-1990s. Pakistan had recently moved from a fixed exchange rate system to a managed float. Briefly multiple exchange rates were considered before moving onto a dirty float in 1999 and then adopting a full-fledged market exchange rate in 2000.(Hyder \& Mahboob, 2005)

From 2000 onwards as the government of General Pervaiz Musharaf took over, the role of adaptive expectations again increased. This can be justified by the events of 9/11 and later Pakistan joining the war on terror. During the same time two factors may have impacted core inflation. One, Pakistan joined the War on Terror and hence began to receive international aid. Two, the relationship between the IMF and the Musharraf government in the initial phases was strained at best. As a sign of good faith, the government took extreme measures to apply the conditions put forth by the IMF. These included, among other things, 
reduction in overall budget deficits, removal or distortions from economy, improved governance and increased spending on poverty. Out of the nine IMF agreements during the 1988-2001 era, only the one in Musharraf era was fully implemented.

\section{Figure 4: Temporal Contribution To Core Inflation}

From 2008 as the PPP government took over, the impact of loans to private sector on core inflation virtually vanishes. As external finance inflows declined, banking sector credit to the public sector was increasing during this time period to finance the rising government borrowing. This rise in government borrowing due to rising budget deficit was due to a weak fiscal structure and increased fiscal decentralization without any clear rules, a large strain on government expenditures due to subsidies and government support of loss making public sector enterprises. During the same time impact of adaptive expectations rose.

\section{Conclusion and Policy Implications}

In this paper we attempt to answer three questions related to the relationship between monetary policy and core inflation, determinants of core inflation and contribution of each determinant to core inflation.

First, does monetary policy have an impact on core inflation? We find that it does have the expected impact through the credit channel and exchange rate channel.

Second, we outline what factors determine core inflation and to what extent. In addition the credit channel and exchange rate channel, adaptive expectations play a pivotal role in determining core inflation.

Finally, to what extent do each of these determinants contribute to core inflation? We find that adaptive expectations have a significant impact on core inflation. Adaptive expectations have the largest impact on core inflation and loans to private sector are the second largest contributor to core inflation.

Why do adaptive expectations play such a large role in determining core inflation? This is particularly important when there is an active monetary policy which targets core inflation in Pakistan. The main question is that is the Central Bank effectively able to curb core inflation through its channels?

\section{Acknowledgement}

We would like to thank Adnan Haider for useful discussions on this topic. Any errors or omissions in this paper are our own responsibility. Views expressed here are those of the authors and not necessarily of the Institute of Business Administration, Karachi, Pakistan. 蹸

\section{References}

Khan, A. A., Bukhari, S., \& Ahmed, Q. (2007). DETERMINANTS OF RECENT INFLATION IN PAKISTAN. Pakistan Insitute of Development Economics.

Agha, A., Ahmed, N., Mubarik, Y., \& Shah, H. (2005). Transmission Mechanism of Monetary Policy in Pakistan. SBP-Research Bulletin Volume 1.

Hamid, N., \& Hamid, J. (1982). Exchange Rate Reform in Pakistan. Economic Development Institute of the World Bank. 
Husain, D. I. (2002). Pakistan and the IMF : 1988-2002. International Expert Workshop . German Foundation for Development .

Hyder, Z., \& Mahboob, A. (2005). Equilibrium Real Effective Exchange Rate and Exchange Rate Misalignment in Pakistan. SBP Conference 2005.

IMF. (2012). IMF Country Report No. 12/35. International Monetary Fund.

Javid, M., \& Munir, K. (2013). The price puzzle and monetary policy transmission mechanism in Pakistan: Structural VAR approach. 29th AGM and Conference PIDE.

Khan , M., \& Schimmelpfennig, A. (2006). Inflation in Pakistan: Money or Wheat? IMF Working Paper WP/06/60.

Khan, A., \& Qasim, M. (1996). Inflation in Pakistan Revisited. The Pakistan Development Review.

Lodhi, M. A. (2007). Evaluating Core Inflation Measures in. Karachi: State Bank Of Pakistan.

Mubarik, Y. A. (2005). Inflation and Growth: An Estimate of the threshhold level inflation in pakistan. SBP-Research Bulletin Volume 1.

Riazuddin, R., Lodhi, M., Ashfaq, M., \& Ahmad, B. (2013, October). A New Measure of Core Inflation in Pakistan No 66. SBP Working Paper Series.

Tahir, S. (2003). Core Inflation Measures for Pakistan. Karachi: State Bank of Pakistan.

\section{Appendix}

Figure A1. Core inflation and Discount Rate in Pakistan.

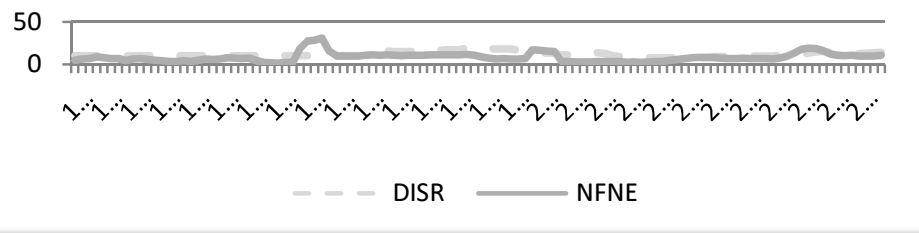

Source: State Bank of Pakistan

Tables and Figures

Figure 1: Core Inflation In Pakistan 1984-2011

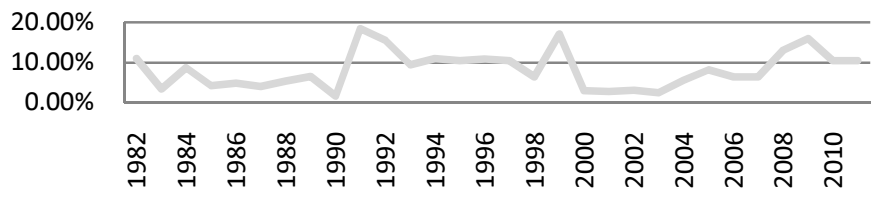


Table 1: List of Variables with Descriptive Statistics

\begin{tabular}{|c|c|c|c|c|c|c|c|c|}
\hline Variable & $\begin{array}{c}\text { Core } \\
\text { Inflation }\end{array}$ & $\begin{array}{c}\text { Growth } \\
\text { in Money } \\
\text { Supply }\end{array}$ & $\begin{array}{c}\text { Discount } \\
\text { Rate }\end{array}$ & $\begin{array}{c}\text { Growth } \\
\text { in Loans } \\
\text { to } \\
\text { Private } \\
\text { Sector }\end{array}$ & $\begin{array}{l}\text { Exchan } \\
\text { ge Rate }\end{array}$ & $\begin{array}{l}\text { T Bill } \\
\text { Rate }\end{array}$ & $\begin{array}{l}K S E \\
\text { Index }\end{array}$ & $\begin{array}{c}\text { Domestic } \\
\text { Governme } \\
n t \\
\text { Borrowi } \\
n g\end{array}$ \\
\hline Source & PBS & SBP & SBP & SBP & SBP & SBP & KSE & SBP \\
\hline Mean & 0.011 & 0.000 & 0.009 & 0.001 & 0.000 & 0.061 & -0.003 & 0.004 \\
\hline Median & -0.004 & 0.000 & -0.181 & -0.019 & 0.001 & 0.112 & 0.013 & 0.003 \\
\hline Maximum & 0.193 & 0.074 & 3.272 & 0.147 & 0.059 & 3.853 & 0.597 & 0.347 \\
\hline Minimum & -0.023 & -0.053 & -3.096 & -0.094 & -0.071 & -3.932 & -0.819 & -0.233 \\
\hline Std. Dev. & 0.042 & 0.030 & 1.371 & 0.065 & 0.029 & 1.744 & 0.194 & 0.140 \\
\hline Skewness & 2.579 & 0.231 & 0.323 & 0.696 & -0.131 & -0.202 & -0.626 & 0.088 \\
\hline Kurtosis & 9.165 & 1.943 & 2.896 & 2.297 & 2.592 & 2.741 & 6.514 & 2.080 \\
\hline Jarque-Bera & 218.053 & 4.493 & 1.449 & 8.215 & 0.792 & 0.776 & 46.957 & 2.959 \\
\hline Probability & 0.000 & 0.106 & 0.485 & 0.016 & 0.673 & 0.678 & 0.000 & 0.228 \\
\hline Sum & 0.867 & 0.001 & 0.769 & 0.088 & 0.038 & 4.914 & -0.261 & 0.316 \\
\hline Sum Sq. Dev. & 0.142 & 0.074 & 150.415 & 0.339 & 0.066 & 243.230 & 3.017 & 1.567 \\
\hline Observations & 81.000 & 81.000 & 81.000 & 81.000 & 81.000 & 81.000 & 81.000 & 81.000 \\
\hline
\end{tabular}

Table Note:

PBS $=$ Pakistan Bureau of Statistics

\begin{tabular}{|l|c|c|c|c|}
\hline \multicolumn{4}{|c|}{ Table 2: Augmented Dickey-Fuller Test of Residuals* } \\
\hline & \multicolumn{2}{|c|}{ Level } & \multicolumn{2}{c|}{ Difference } \\
\hline Variable & t-Statistic & Probability & t-Statistic & Probability \\
\hline Discount Rate & -0.2711 & 0.5866 & -9.7158 & 0.0000 \\
\hline Domestic Government Borrowing & 2.4362 & 0.9964 & -7.1662 & 0.0000 \\
\hline Growth in KSE Index & -7.3450 & 0.0000 & &. \\
\hline Growth in Loans to Private Sector & -2.0101 & 0.5898 & -13.2802 & 0.0000 \\
\hline Growth in Money Supply & -3.0259 & 0.1297 & -7.8969 & 0.0000 \\
\hline Core Inflation & -1.8055 & 0.6963 & -8.2601 & 0.0000 \\
\hline Growth in Exchange Rate & -5.9427 & 0.0000 &. &. \\
\hline T-Bill Rate & -2.0379 & 0.5723 & -6.5947 & 0.0000 \\
\hline
\end{tabular}

*(optimal lag length is selected by AIC) 
https://ir.iba.edu.pk/businessreview/vol10/iss1/5

DOI: https://doi.org/10.54784/1990-6587.1313

Business Review - Volume 10 Number 1

January - June 2015

Table 3: Dependent Variable Core Inflation (Non Food Non energy)

\begin{tabular}{|c|c|c|}
\hline Variable & Coefficient & t-Statistic \\
\hline \multicolumn{3}{|l|}{ Constant } \\
\hline \multicolumn{3}{|l|}{ Adaptive Expectations } \\
\hline Core Inflation $(\mathrm{t}-1)$ & 0.8776 & 12.8836 \\
\hline Core Inflation (t-4) & 0.1048 & 1.2854 \\
\hline Core Inflation $(\mathrm{t}-6)$ & 0.141 & 1.7505 \\
\hline Loans to Private Sector as a Ratio of Money Supply ( $t$ ) & 0.1587 & 2.4779 \\
\hline Loans to Private Sector as a Ratio of Money Supply (t-4) & -0.1486 & -2.6837 \\
\hline Exchange Rate (t) & -0.0259 & -0.438 \\
\hline Exchange Rate (t-4) & 0.1383 & 2.3113 \\
\hline Real GDP Growth & -1.4118 & -3.1806 \\
\hline Real GDP Growth (t-4) & -0.9302 & -1.8336 \\
\hline T-Bill Rate (t) & -0.0022 & -1.5854 \\
\hline T-Bill Rate (t-4) & 0.0001 & 0.0963 \\
\hline Growth in KSE Index (t) & -0.0049 & -0.5584 \\
\hline Growth in KSE Index (t-4) & 0.0024 & 0.2443 \\
\hline Growth in Money Supply & 0.1075 & 1.1702 \\
\hline Growth in Money Supply (t-6) & -0.0043 & -0.0623 \\
\hline Discount Rate (t) & 0.0012 & 0.7815 \\
\hline Discount Rate (t-6) & 0.000 & -0.0052 \\
\hline Domestic Government Borrowing as a Ratio of Real GDP ( $t$ ) & -0.0345 & -1.284 \\
\hline Domestic Government Borrowing as a Ratio of Real GDP (t-6) & -0.0224 & -0.8489 \\
\hline Dummy for 1991 & -0.0019 & -0.1592 \\
\hline Dummy for 1999 & 0.1134 & 7.4159 \\
\hline Dummy for 2009 & 0.0172 & 2.7011 \\
\hline R-squared & & \\
\hline Adjusted R-squared & & \\
\hline Durbin-Watson stat & & \\
\hline \multicolumn{3}{|l|}{ Breusch-Godfrey Serial Correlation LM Test: } \\
\hline F-statistic & \multicolumn{2}{|c|}{0.5251} \\
\hline Probability & \multicolumn{2}{|c|}{0.7865} \\
\hline Obs*R-squared & \multicolumn{2}{|c|}{4.7125} \\
\hline Probability & \multicolumn{2}{|c|}{0.5812} \\
\hline
\end{tabular}


https://ir.iba.edu.pk/businessreview/vol10/iss1/5

DOI: https://doi.org/10.54784/1990-6587.1313

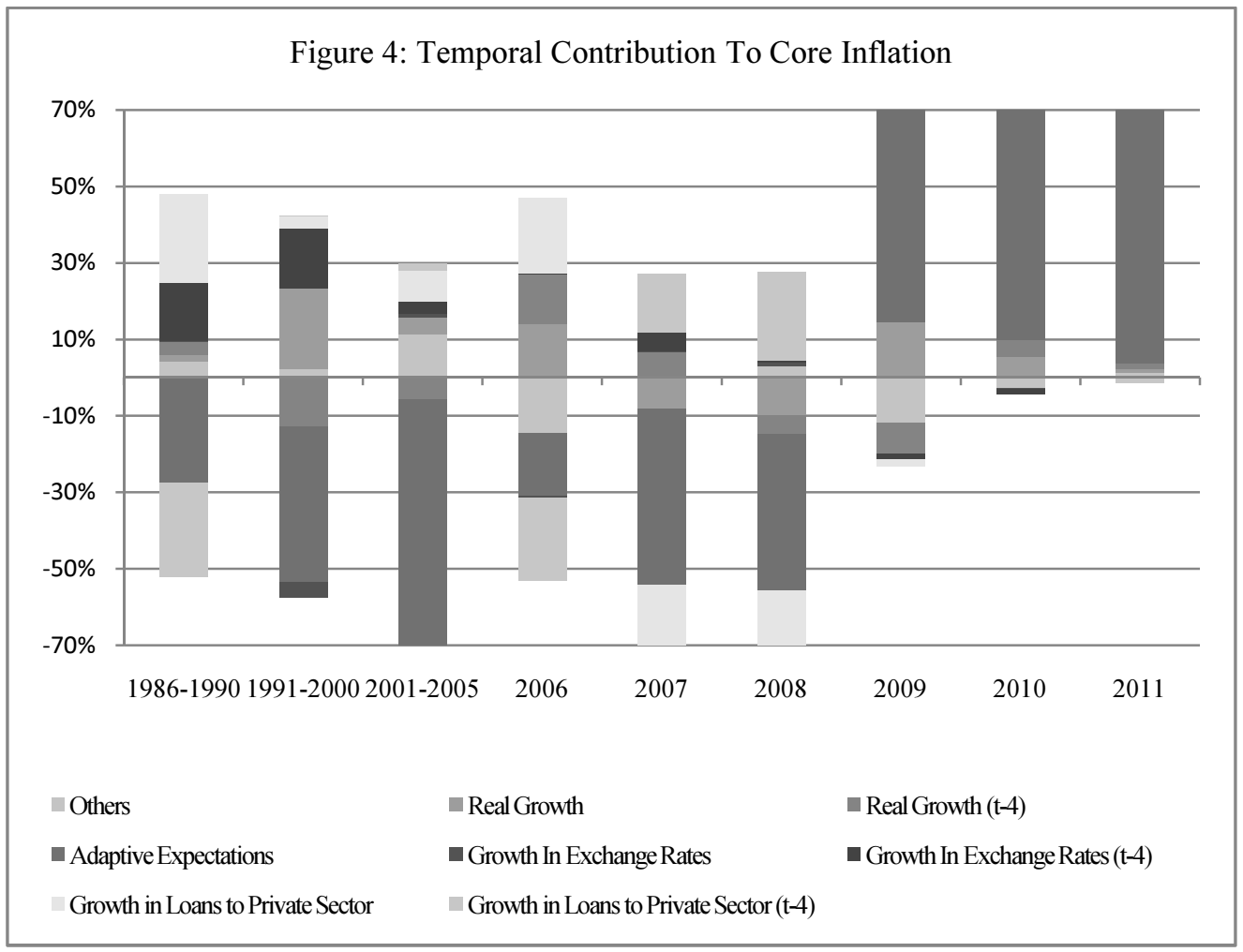


https://ir.iba.edu.pk/businessreview/vol10/iss1/5

DOI: https://doi.org/10.54784/1990-6587.1313

Business Review - Volume 10 Number 1

January - June 2015

\section{MOTIF}

If there were in the world today any large number who desired their own happiness more than they desired the unhappiness of others, we could have paradise in few years

Bertrand Russel 